\author{
ANNA ŁOŚ-TOMIAK \\ MAGDALENA DALECKA
}

\title{
The concept of social responsibility in non-governmental organizations
}

Anna Łoś-Tomiak, Ph.D., Magdalena Dalecka, Ph.D. University of Zielona Góra Faculty of Economics and Management

\section{Introduction}

The shape and sustainable development of regions is affected by many factors. The members of local communities gathered in all sectors of social and economic life have the contribution in meeting needs and achieving the state of economic welfare. Particular citizens realize themselves in first of all nongovernmental organizations where they participate actively in the implementation of missions. The guarantee of the sustainable development is also rapidly acting local government. And in the end, the role, not to be underestimated, in determining the level of socio-economic development is played by a market sector.

All mentioned groups of actors model the external environment through the implementation of their statutory objectives: economic - in the case of business enterprises, social - with reference to nonprofit organizations and public - under the responsibility of local government structures. They operate on the basis of different 
sources of funding. More and more often, however, they are identified by their participation and involvement in, less formally defined on local market, a social dialogue. Additionally, they more and more often balance in their policy statutory objectives with the category of the common good, social solidarity, social development, environment protection. More and more often also, they pay more attention to ethics, respect for the rights, cooperation and cross-sector partnership.

The co-existence and cooperation of entities - state, market and civil institutions is essential to establish stable and sustainable development. It is important to achieve social welfare and meet social needs at the expected level, using all available complementary potentials (Nasze...1996, p. 233). „The cooperation of third sector with other sectors and social actors strengthens all social segments involved in the process of cooperation and a social system as a whole. It contributes to a better more effective functioning of a commune, ministry, local newspaper, business enterprise, and finally - the institution of state, which due to this cooperation becomes simply better and more efficient, more stable and resistant to crises, more effectively satisfying its citizens' needs". It shows that the orientation of the run activity to the social needs and the region brings positive connotations not only for the recipients of particular actions but also for the entities performing certain tasks.

Such a definition of the management strategy of different types of organizations and entities, whose basis is the aspiration for the social progress and sustainable development of societies and regions, is defined as social responsibility. It grew up from the modernization of definitions and expectations towards business entities and the increased conviction of many of them as for the validity of such actions. Companies, which are guided by the economic calculation and the undertaken activities concentrate on profits, considered to be beneficial, appropriate and necessary to take pro-developmental and prosocial initiatives as well.

The universalism of the function of management in market enterprises gave rise to adopt the pattern of conduct on the ground of other areas of socioeconomic life. The strategy of social responsibility has been also used in other sectors, first of all in the sector of non-governmental organizations.

Thus, the aim of the paper is to show correlations and similarities between a non-governmental sector and market, including the ones defined by the theories of economics and management. The analysis will be given to the concept of social responsibility, which, although initiated and implemented by mainly business enterprises, is also used in the activities of the third sector 
entities. For the reason that it is interpreted as only the impact on the employees of companies and the influence of the social environment of enterprises, can be implemented in the area of the operation of non-profit institutions.

\section{The essence of corporate social responsibility}

The activities of companies, according to which the realization of economic objectives takes into consideration the ecological and social needs of the region, and the undertaken actions have a long-term nature and comply with ethical norms, is the essence of social responsibility. It is the policy of enterprises in such a form as to balance high economic efficiency with social interest (Walkowiak, Krukowski 2009). It is the management of market entities as to allow for the efficient, in the long-term perspective, realization of the company's goal; ensuring the proper development of relations with key stakeholders, which respects the proceedings in accordance with the law and socially accepted ethical norms (Gliński 1998, p. 51). The enterprises, which voluntarily in their commercial operation and relations with interested parties take into consideration the social and ecological issues, are part of a promoted by the EU and more and more dynamically growing trend of corporate responsibility.

Corporate social responsibility, internalizing ethical and legal norms, goes beyond formal regulations determining the operation of enterprises. It is voluntary (Żemigała 2007, p. 100). It does not result from the accepted rules, regulations, catalogues of business conduct, but describes the quality of their performance. It is used in each area of the entity's influence. It concerns social obligations. It is a response to social demand. It describes social sensitivity (Nakonieczna 2008, p. 19).

Corporate social responsibility is not, what is very important, an additional form of activity run next to the commercial operation, but the way of its implementation. It is still a novel manner of management, which, apart from strategic objectives mainly of an economic and image nature, includes the expectations and needs of stakeholders. It takes into account not only the needs of employees or enterprise management, but also the external social environment, i.e. suppliers, clients, shareholders, customers of externalities of companies' business, social organizations, institutions, etc. 
It is logical that for many companies, the basis for the adoption of such a strategy for the realization of the objective is, except for recognizing the rank of the common good and social justice, also the willingness to build prestige and develop the advantage on the competitive market in the longterm. Positive relationships and relations with stakeholders, well rooted both in the strategy of managing the company and in the perception of environment, can significantly increase the efficiency and effectiveness of the entity's operation. Despite the fact that they can be, especially in the initial period, expensive, they are cost-effective and beneficial in the long-term.

It is necessary to mention that still for many Polish companies - although their consciousness has an increasing tendency (Bojar 2007, p. 15) - the implementation of CSR rules is an additional and unnecessary expense, as it is often identified with PR as well as defined only as media, socially legible campaigns for particular entities or needs. A large group are also companies that carry out the idea of a social impact not fully consciously. Accepting that a particular location of the company in a particular social context naturally reflects the operation of the enterprise and its impact on the environment, mainly employees and local community. Precisely defined strategic implementation of social responsibility rule concerns, in a big degree, large international corporations, market leaders, companies thriving economically, externally obliged to implement particular patterns and tools of impact (Gasparski 2004, p. 67).

One could argue that Polish companies, the majority of which are small and medium-sized firms, carry out the concept of social responsibility only through assistance, an altruistic and philanthropic activity. The external impact is more the effect of the identification of a social problem or issue, a sense of social injustice or a particular need rather than the effect of a long-term firm strategy, which should result in a stable, highlevel economic situation of the entity.

To a large extent, due to the social commitment of enterprises, other entities, social, non-governmental organizations are able to perform more effectively their mission and the needs of particular groups of stakeholders are secured quickly and effectively. The undertaken actions are not 
of a media nature, sometimes are accidental or individual, but they not only satisfy needs, but also activate individuals and groups, promote the idea of civil society and in a great degree, give a mandate to the existence and development of non-governmental sector.

\section{Business versus non-governmental organizations sector}

Non-governmental sector consists of private organizations, which act socially and not for profit. The basis for its actions are individual and real human needs, whose satisfying should be consistent with the accepted and socially acknowledged rules and values. The priority for non-profit organizations is the common good and social solidarity (cf. Green Paper 2001). This sector is complementary. It realizes such functions, whose performance is not entirely state's responsibility, due to the accepted rules and possibilities to perform social tasks as well as which are not interesting for business entities due to the lack of economic motivation to undertake these actions (cf. Raport... 2007, Krzyżanowska 2000, Iwankiewicz-Rak 1997). It was created as „, a supplement of a private and public sector "in response to" insufficient realization of social tasks by the state"( Schimanek 1997, p.37).

The justification of the functioning of non-governmental entities in the market economy is the conviction of the market failure in the social sphere, in relation to the production of public goods and services, not always effective and not entirely efficient, the action of the state in the area of social policy within ensuring the social safety to citizens, satisfying their needs and achieving welfare, which guarantees satisfaction and high utility from the consumption of goods. Between them and other sectors, that is mainly market, there is a constant cooperation. Non-governmental organizations, using the funding from business, are the intermediary on the one hand - realizing their statutory goals, providing for individuals and groups burdened with a social issue or reacting to social injustice. On the other hand, however, they become the final beneficiary of benefits, regulating and enhancing their performance on the basis of the support of market sector.

Regardless of the source of obtaining financial resources, each activity of a non-profit institution is conducted with the participation of money, each is based on the capital coming from the performer activity, each employs employees. All mentioned components give the right to assimilate the third sector institutions to business organizations. It is not, however, proper to equate 
both types of entities. Money in the process of exchange is the factor, on the basis of which it is possible to make comparison of non-governmental organizations with market entities. Both forms realize their objectives with its participation. It is not, however, justified to treat equally both entities. In the case of commercial enterprises financial transfers take place directly between a seller and purchaser, and their basis are expected benefits coming from the consumption of goods and information about their quality and price. On the other hand, exchange transactions between non-governmental organizations, which determine the supply of products, and their clients are accompanied by different forms of payment. Sometimes the beneficiary covers the costs of the granted benefit, however, the more often practiced form is an indirect exchange, which takes place through the tax office, whose essence is the participation of the state in financing social tasks performed by non-governmental organizations. It is also common that generating and granting benefits is secured financially by people not participating directly in the exchange, i.e. funders, donors or sponsors and volunteers (Krzyżanowska 2000, p. 2).

The differences between non-profit organizations and business entities are also perceived in motivation and aim of the action. The first ones are guided in their actions by the willingness of benefit for the society, to meet individual and collective needs. Selecting the scope of action, type of provided goods and services, they are directed by real needs, the character of recipients, their satisfaction. In their case, the participation of money in the exchange processes does not result in gathering the income for the participants of the organization, which becomes a basic criterion of the performance of market institutions.

Moreover, the recipients of market goods of enterprises are their purchasers, who are obliged to pay a certain amount for the goods. The consumers of nongovernment organizations are the persons, who receive a benefit or service regardless of the fact whether it is followed by a direct or indirect payment, as well as persons not using the provided services, but contributing to the development of the organizations by financing or organizing them or by volunteering, or by acting for the development and promotion of the sector and taking advantage of external effects resulting from its operation (Iwankiewicz-Rak 1997, p. 15).

Both kinds of entities are also differentiated by monitoring and control. The evaluation of the enterprise operation is carried out mainly by consumers of their goods, whereas the observation of non-profit institutions is done, beside recipients of benefits, by the whole society (Knecht 1999, p. 24).

Thus, although it is possible to distinguish elements common for commercial and non-profit entities, it is difficult to identify them with each other. It is also not 
advisable to replace ones by the other or question the validity of the functioning of any of both forms of activity in the market economy.

The good practices of the cooperation of entities and using their good patters of functioning should rather be stressed. Therefore, the rules of social impact defined thanks to enterprises should be transferred on the ground of nongovernmental sector.

The presence of non-governmental institutions acting not for profit and being guided by the social good and not the maximization of income in the market economy, can be explained and justified in many ways. It is necessary to assume that the market, although it is the best way to increase the economic effectiveness, although it is the condition of sustainable development and the economic growth, is not successful in an equal degree in all aspects of life. It ensures the effective and efficient functioning of the economy when it guarantees the balance between the expectations of purchasers and producers, that is the supply of goods reported by producers is balanced by consumption demand. If the conditions determining the functioning of the economy allow for obtaining legible information from the market, being the basis of rational behaviour of both groups of entities, it is possible to assume that the market mechanism functions well and allows for the optimization of utility (Iwankiewicz-Rak 1997, p. 39).

Unfortunately, the existing in practice market does not solve all problems occurring in the economy. Its imperfection can be observed the best in the social sphere, which implies free and universal benefits in the area of protection and health care, education or social services, that is in the sphere for which the production of public goods is typical, connected with costs and not guaranteeing the return on the investment, a profit or self-financing. It is inefficient in the public sphere. It does not work effectively in the sector of the production of goods and social services. It is not a remedy for macroeconomic problems resulting from the pauperization of society or the requirements of the work market. It is also not the best way for the redistribution of income (Knecht 1999, pp. 25-26).

In relation to the issues presented above and the scope of problems, nongovernmental organizations are more successful, as on the basis of independent decisions and the possessed resources perform social tasks, produce goods, whose production market sector is not interested, and in production of which the state fails. They complete the state and replace not interested business entities, create, through private actions, public goods, that is the ones, which are free for all citizens, which can be indivisible and are meant for common consumption (Golinowska 1994, p. 38). The goods that are not private, thus the rule of exclusion does not refer to them, related to purchasing the good 
by a particular user and there is not a competition about their consumption, which results from the possibilities of exploiting them by all the interested.

The production and distribution of public goods is the basis for distinguishing main economic conceptions, being the justification for the functioning and development of non-governmental sector. It is possible to distinguish the theory of heterogeneous demand, the theory of failure of contacts and the theory of social resources (Kozłowski 1998, pp. 28-29).

The first one, created by Burton Weisbrod (Burlingame 1996, p .22), assumes that the production and distribution of public goods, due to the lack of competition and exclusion, and the lack of profit at the same time, which is the priority of the market enterprises, is not an interesting object of actions for these entities. A low economic motivation decreases the participation of market entities in the trade of that kind. Such a requirement is imposed on the state sector, which, using political mechanisms, is able to produce and divide public goods. However, it is impossible to produce from political funds by public entities sufficient number of goods in terms of quantity and quality, which would satisfy all reported social needs. Definitional heterogeneity of demand, that is the scheduling the validity of certain types of goods and, being the result of the difference of opinions of particular citizens, the ranking of objectives, results in the production of only some of them, and therefore satisfying only some needs. The right of implementation, from public funds, of only some social goals, satisfying only selected social needs, the basis of which are the decisions of voters, determines the occurrence of a group of not satisfied social needs, which level is the higher, the more heterogeneous is the society, which hinders reaching the consensus and meeting many social interests (Leś, Nałęcz 2002, p. 47).

Being the result of market imperfections, as „ineffective mechanism of distributing public goods, resulting from both the lack of exclusion and/ or competition and the free-rider problem as well as the existence of positive and negative external effects" and the imperfections of the government treated as "the weakness of democracy in meeting the expectations of all citizens concerning public goods", that is particular "allocation decisions and the limitation of public resources" (Golinowska 1994, pp. 40-41, the operation of non-governmental organizations as the provider of public goods and services finds justification. There is an increase of the rank of institutions, established and existing to provide services, the payment of which lies beyond the financial possibilities of the state, and for which the voter is not willing to pay in a form of taxes, that is emerging from the will of the citizens, entities, which are

81

ANNA ŁOŚ-TOMIAK

MAGDALENA DALECKA 
supposed to satisfy the demand for public goods. The organizations that enable to produce and distribute public and essential goods indispensible to reach social welfare, the financing of which results from voluntary decisions of donors, interested in the development of particular discipline or elimination of certain issues and problems (Michalak, Wilkin 2003, pp. 49-50).

The other conception explaining the origin and development of nongovernmental sector, being based on market imperfections in creating collective goods, is the conception by Henry Hansmann, connected with the weaknesses of market contracts (Burlingama 1996, p. 22). It concerns the production and distribution of private goods, the provision of which is attributed to the market sector. However, due to the situation of the market limitation as a mechanism of allocation, the production and division of certain goods is involved in the third sector (Leś, Nałęcz 2002, p. 48). The reason for the market failures, justifying the necessity of the functioning of non-governmental organizations, is ",a relatively high asymmetry of information referring to the sold/purchased product", or a lack of legible, clear data, on the basis of which a consumer could make a rational decision about the purchase of certain goods as well as obtain the knowledge about the benefits from the consumption. Such a situation can be often typical of the turnover, where there is a different purchaser and a different consumer of a certain good, or when a product is highly specialized and technologically advanced.

Definitional contract failure is based on the fact that the information the good and service purchasers obtain from the market can be distorted, not include reliable data on the quality, which can cause a temporary increase of the demand for certain goods according to the expectations of producers, the basis of which is, to a large extent, the profit, but does not give an overview on a real state of things, which in the long-term can cause the decrease of trust to producers and thus the restriction of demand. Obtaining the desired knowledge on the purchased goods and services, which could diminish the asymmetry of information, will force the necessity of additional expenses, which will result in the growth of the costs of transaction, which will cause mistrust between market participants, and eventually inefficiency of its operation.

The remedy for the limited trust of consumers and audience of the organization can be the resignation of the producer from the profit, which is especially important with reference to the production and division of social goods and services: "the demand for some private goods can be directed to non-profit institutions, which due to smaller costs of transactions will be more efficient in providing them than the market" (Michalak, Wilkin 2003, p. 51). Thus, the 
organizations, which are in fact not directed to achieve the economic surplus, and having one, dedicate it to implement statutory goals, are much more trustworthy providers of social services than commercial entities. They are more flexible, can adapt the supply of their goods to the request quicker, react stronger to the environment needs (Dziewulski, Skowron 1999, p. 19).

Moreover, the third sector organizations use to a large extent the external financing, the resources coming from donations of donors, who are not able to verify whether the funds they provided are issued in accordance with established specifications. Thus, the information about not distributing profits between the participants of non-governmental organizations contributes to the growth of the trust of donors for these institutions and motivates them to provide more. The theory assumes that the binding market contract, in which consumers on the basis of information about the quality of goods make decisions about purchasing them, is unreasonable, and the guarantee of the effective and efficient provision of services of a high level are, having social trust, non-profit institutions (Hudson 1997, p .216).

The complementation of presented theories can be the conception by Estelle James, including the supply of services as a factor explaining the development of non-governmental organizations. The essence of the functioning of social organizations is included in the proper, in accordance with accepted internalized values and interests, motivation, under the basis of which there is social good. Supporting the motivation with a certain way of financing results in a range of specific, desired goods and services. That supply would be shaped by so-called social entrepreneurs, willing to create and run non-governmental organizations, acting for meeting collective needs by providing goods or services that the state is not responsible for and that are not realized by the market (Michalak, Wilkin 2003, p. 52).

\section{Social responsibility of non-governmental organizations}

Despite many similarities, market and non-governmental sector differ a lot. Cooperating, however, they contribute to the more efficient satisfaction of needs and regulations of the external environment. Social expectations are increasing towards both of them. Both base their functioning on work. Both have an impact on the condition and level of meeting needs by individuals and societies. Both care about the development of a good image, which would give economic benefits to enterprises from the sale of goods and services, to non-governmental organizations, however, - the interest of donators, participants and beneficiaries. 
Thus, similar to business, also non-governmental organizations are more and more often obliged to modernize their actions in accordance with the principles of social responsibility, which would refer to the personal internal potential of entities and to external stakeholders - the recipients of services and benefits, donators and the society.

Adapter from the activities of market entities the principles of the social responsible management refer to both the profitable business and non-profit nongovernmental organizations. The first of them is mainly described by the fact of running a business activity by non-profit sector - often by external dependent companies that are subject to the same legal and financial regulations as business. The second, however, is directly connected with the implementation of statutory objectives, corresponding to the profile of non-productive enterprises.

The legitimacy of introducing to the management system of the third sector entities the demands of social responsibility is understandable. It is obvious that if non-governmental organizations employ paid staff, but also when their business is based on volunteering and use the social capital of their members, the application responsible rules of conduct towards them is beneficial and appreciated. It concerns, among other things, creating certain motivation systems, pro-health programmes, caring about well-being and ergonomic conditions of work, using flexible forms of benefits and working hours.

Above all, however, the justification of the reason of the functioning of nonprofit entities in accordance with the arguments of social responsibility should be found in the essence of the sector operation. Non-governmental organizations are still the answer to social demand, the existence of unsatisfied needs, injustice and social inequalities. Their actions are often directed to inefficient persons and groups, lost in the world of hard market rules, burdened with social issues. Their activity has a nature of assistance. It often determines the level and quality of the functioning of beneficiaries in the society. It all obliges non-governmental organizations to modify the manners of management and implementation of tasks in a socially responsible way.

Non-governmental sector should also correspond to the whole society. By regulating the status quo, determining the hierarchy of social needs, realizing public tasks, using public resources, or shaping the environment by external effects, it should act responsibly. Financing its activity from the budget resources, performing statutory tasks due to targeted subsidies, and also using gifts, payments, collections or $1 \%$ of income tax, it imposed on itself the obligation to clear and report, i.e. is responsible for the effective and in accordance with the goal spending amounts. 
Finally, the social responsibility of non-governmental organizations is visible, similar to the market sector, in conducted campaigns, social actions, projects and programmes for local communities. For most non-governmental entities, the impact on local community and shaping social consciousness is natural. Many of them were appointed for this objective.

\section{Conclusions}

In conclusion, it must be admitted that universalism, quality, or the universality of the principle of social responsibility allows for their realization in the areas of the operation of many entities. They can be identified not only by business enterprises, but also by the structures of local administration, public institutions and non-governmental sector. For non-profit entities the impact on the local community and the development of the region is a natural phenomenon. Many of them were appointed for this objective. The legitimacy of the socially responsible management in the case of non-government sector defends itself. The more when the analysis of the activity of non-profit entities will be conducted by the participated persons, society, donators, beneficiaries, members, employees.

\section{Summary}

The concept of social responsibility in non-governmental organizations

The paper presents the idea of social responsibility, which is adequate for modern and efficient management of the enterprise. The analysis of the interdependence of the market and nongovernmental sector has been made. The article includes the presentation of the justification for the existence of non-profit institutions as the entities that bridge the gap between the sector of enterprises and the state. The attempt has been made to prove that the universal principles, typical of corporate social responsibility, could be also applied in the management of non-governmental sector entities.

Key words: corporate social responsibility, social responsibility of organization, nongovernmental organizations, non-profit institutions. 


\section{Streszczenie}

Koncepcja społecznej odpowiedzialności w organizacjach
pozarządowych
W artykule przedstawiona została idea społecznej odpowiedzialności, która jest właściwa dla nowoczesnego i skutecznego zarządzania przedsiębiorstwem. Dokonano analizy współzależności rynku i sektora pozarządowego. Przedstawiono uzasadnienie dla istnienia instytucji non-profit, jako podmiotów wypełniających lukę pomiędzy sektorem przedsiębiorstw a państwem. Podjęto próbę udowodnienia, że charakterystyczne dla społecznej odpowiedzialności biznesu, uniwersalne zasady, znajdują zastosowanie również $\mathrm{w}$ zarządzaniu podmiotami sektora pozarządowego.

Stowa

kluczowe: społeczna odpowiedzialność biznesu, społeczna odpowiedzialność organizacji, organizacje pozarzadowe, instytucje non-profit.

\section{References}

1. Bojar M. (2007), Społeczna odpowiedzialność w biznesie, Lublin.

2. Burlingame D.F. (1996), Dlaczego organizacje non-profit? Amerykański punkt widzenia, w: Sektor pozarządowy w zmieniającym się społeczeństwie pod red. B. Synaka, M. Ruzica, Uniwersytet Gdański, Instytut Filozofii i Socjologii, Indiana University, Center on Philantopy, Gdańsk, Indianapolis.

3. Dziewulski J., Skowron S. (1999), Organizacje non-profit w gospodarce, „Ekonomika i Organizacja Przedsiębiorstwa” nr 12.

4. Gasparski W. (2002), Wykłady z etyki biznesu: Nowa edycja, wyd. WSPiZ, Warszawa.

5. Gliński P. (1998), Wspótpraca organizacji pozarzadowych z innymi sektorami, w: Opiekuńczość czy solidarność? Obywatelskie formy współpracy z władzami lokalnymi oraz pomocy społecznej, pod red. G. Skąpskiej, Wyd. Fundacja Międzynarodowe Centrum Rozwoju Demokracji, Kraków.

6. Golinowska S. (1994), Nowa struktura instytucji sfery społecznej, Instytut Pracy i Spraw Socjalnych, Warszawa.

7. Golinowska S. (1994), Polityka społeczna państwa w gospodarce rynkowej, PWN, Warszawa.

8. Green Paper (2001). Promoting The European framework for the Corporate Social Responsibility, European Commission, Brussels. 
9. Hudson M. (1997), Bez zysków i strat. Sztuka kierowania organizacjami sektora pozarzadowego, Fundusz Współpracy, Program Phare Dialog Społeczny, Warszawa.

10. Iwankiewicz-Rak B. (1997), Marketing organizacji niedochodowych. Wybrane problemy adaptacji w warunkach polskich, Wydawnictwo Akademii Ekonomicznej we Wrocławiu, Wrocław.

11. Knecht Z. (1999), Promocja marketingowa w sektorach gospodarczych $i$ organizacjach non-profit, Wydawnictwo Wyższa Szkoła Zarządzania, Wrocław.

12. Kozłowski S.G. (1998), Systemy ekonomiczne, Analiza porównawcza, Wydawnictwo UMCS, Lublin.

13. Krzyżanowska M. (2000), Finansowanie organizacji pozarzadowych, "Marketing i Rynek" nr 1.

14. Leś E., Nałęcz S. (2002), Potencjał ekonomiczny i społeczny sektora non-profit w Polsce. Wybrane wyniki badan międzynarodowych sektora non-profit, w: Samoorganizacja społeczeństwa polskiego: trzeci sektor, pod red. Piotra Glińskiego, Barbary Lewenstein, Andrzeja Sicińskiego, przy współpracy Piotra Frączaka, Ryszarda Skrzypca, Wyd. IFiS PAN, Warszawa.

15. Michalak T., Wilkin J. (2003), Rynek, społeczeństwo obywatelskie, państwo a sytuacja grup zmarginalizowanych - ujecie ekonomiczne (na przykładzie sytuacji w polskim rolnictwie), [w:] W stronę aktywnej polityki społecznej, pod red. T. Kaźmierczaka i M. Rymszy, Instytut Spraw Publicznych, Warszawa.

16. Nakonieczna J. (2008), Społeczna odpowiedzialność przedsiębiorstw międzynarodowych, Warszawa.

17. Nasze światowe podwórko. Raport Komisji Do Spraw Światowego Kierowania (2006), tłum. G. Górska, PWE, Warszawa.

18. Raport (2007) Społeczna odpowiedzialność biznesu w Polsce. Wstępna analiza, UNDP, Warszawa.

19. Schimanek T. (1997), Obywatelskie niepostuszeństwo w świetle kontrolnych $i$ innowacyjnych zadań trzeciego sektora, w: Między lobbingiem a akcją bezpośrednią (metody działania obywateli) pod red. P. Frączaka, biblioteka Asocjacje nr 2 i biblioteka Zielonych Brygad nr 21, WarszawaKraków.

20. Walkowiak R, Krukowski K. (2009) Społeczna odpowiedzialność organizacji. Od odpowiedzialności do elastycznych form pracy, Olsztyn.

21. Żemigała M. (2007), Społeczna odpowiedzialność przedsiębiorstwa: budowanie zdrowej, efektywnej organizacji, Kraków. 